\title{
Impact of Existent Culture on the Performance of Mobile Telecommunication Companies in Nigeria.
}

\author{
Ajayi Christiana Olalounpe \\ Department of Business Administration, Joseph Ayo Babalola University, P.M. B. 5006, Ilesa, Osun State, \\ NIGERIA
}

\begin{abstract}
The study identified the culture that existed in mobile telecommunication companies in Nigeria. The population for the study comprised all employees of eight telecommunication companies in Southwestern Nigeria namely Mtn, Globacom, Etisalat, Airtel, Visafone, Odua Network, Starcomms and Multilinks. The study used of twostage sampling technique. At the first stage, purposive sampling technique was used to select three companies namely Mtn, Glo, and Etisalat because of their wider network coverage. Also, purposive sampling technique was used to select Lagos, Oyo and Osun States in Southwestern Nigeria where major offices of these selected companies were located. At the second stage, convenience sampling was used to select 90 employees from Mtn, 80 employees from Globacom and 30 employees from Etisalat and this was stratified into three categories (senior, middle and junior). Primary data and Secondary data were used in the study. The responses to the questionnaires were analyzed using Statistical Package for Social Sciences (SPSS), which generated the frequency distribution, means, Standard deviation and Durbin Watson statistics among other responses. The hypothesis of this research was tested at 0.05 level of significance using Durbin Watson Statistics hinged on factors influencing the culture of mobile telecommunication companies. The study found out that teamwork spirit, effective communication, creative synergy, viable business strategy; among others will help in improving performance of mobile telecommunication companies. The study also found out that there are some factors which could influence the existence culture of mobile telecommunication companies in Nigeria. These include National culture; Government policies; Industry norms; Macroeconomics; and their Legal system. This study however recommended that managers should endeavour to strengthen the existent culture in their companies and employees should ensure conformity with its usage.
\end{abstract}

Keywords: Impact, Organization, Existent Culture, Business Performance, Mobile Telecommunication Companies.

DOI: $10.7176 / \mathrm{EJBM} / 11-5-10$

\subsection{Introduction}

Culture is an indispensable factor to be considered in corporate building, because it is a pattern of mutual assumptions, standards and idea governing the way employees within an organization think about or act on problems and opportunities. In this context, culture is to be reckoned with because it robs on the orientation of decision makers as well as the citizen of any nation. Culture also dictates the performance of business both in private and public sector. The mobile telecommunication sector is not an exemption in this perspective.

Significant understanding of organizational culture will help corporate organizations to know how it influences their activities and work out means of improving them. Special interests have been placed on the organizational culture virtually in all organizations because of its relevance. Employees are depending on the existing culture to behave rightly and accordingly. The organizational culture that is well defined will aid concentration, reduce confusion, strengthen the skills, instincts, abilities, processes and resources that organizations and employees need to survive, adapt in the fast changing world.

Although, organizational culture cannot be seen but they exist to the point that each employee is aware of its existence and the newly recruits must be familiar with it. Cultures of an organization need to be considered as the component of organizational characters which is having effect on employee performance. Organizations pay attention to their culture which they uphold in order to do better than their competitors. In other words, organizational culture will help in doing excellently or performing better than the competitors and also strive to sustain the competitive advantage which in turn helps them to contribute to the national development. Hence, continuous existence of the organization and realization of its goals require taking strong culture as their priority. 
It should be noted that the efficacy of organizational culture will determine how the employees will agree on a particular pattern of behaviour.

Organizational culture enables employers to overcome potential hindrances to their competitive advantages sustainability, create alternative cause action to issues and ultimately preserve the organization all over the time. The success of any organization depends largely on the organizational culture and what really differentiate successful companies from others are their culture (Cameron and Quinn1999).

\subsection{Research Questions}

i. What are the existent cultures in mobile telecommunication companies in Nigeria?

ii. What are the factors that influence the existent culture of the mobile telecommunication companies?

\subsection{Objectives of the study}

The general objectives of the study are to examine if existing culture in mobile telecommunication companies in Nigeria has influence on its business performance.

- To identify the existing culture in mobile telecommunication companies in Nigeria.

- $\quad$ To assess the factors that influences the culture of the mobile telecommunication companies in Nigeria.

\subsection{Research Hypothesis}

$\mathrm{H}_{\mathrm{o}}$ : Organizational Cultures do not have any significant influence on performance of mobile telecommunication companies in Nigeria.

$\mathrm{H}_{1}$ : Organizational Cultures have significant influence on performance of mobile companies in Nigeria.

telecommunication

\subsection{Conceptual Review}

\subsection{Concept of Organizational Culture}

An organizational culture virtually depends on the segment of the business, the past history and the employees' behaviour and perception and nature of communication pattern. Buchanan and Huczynski (2004) defined organizational culture as the collection of relatively uniform and enduring values, beliefs, customs, traditions and practices that are shared by an organization's members learned by new recruits, transmitted from one generation of employee to the next.

The purpose of organizational culture is to control the way employees interrelate at their workplace. A healthy culture encourages the employees to stay motivated and sincere towards the Management. The culture of a workplace mostly spur the workers into action that will lead them to better performance predefined policies which guide the employees and give them a sense of direction at the workplace. It is very important that every business organization should have sets of guideline for the employees to work accordingly; each person is cleared about his or her roles and duties in the organization and how to accomplish the responsibilities given before the stipulated time. 


\subsubsection{Existing Culture in Mobile Telecommunication Companies}

- Customer-oriented culture: All employees are trained to serve customers better and to enable any employee to help customers when needed. Employees are empowered to resolve customer problems in a way the way that will make the customers to re-visit the organization or feel satisfied for the service delivery.

- Competitiveness culture: In global world, there is keen competition among the telecommunication companies and they compete for various market and available resources, just to meet up with their set goals and objectives. An organization with a competitive culture will look for all available opportunities to surpass others in the industry.

- Teamwork: This is a situation in an organization whereby there is a collaborative effort of a team to achieve a common goal or to complete a task in the most effective way. This concept is a crucial part of a business, as it is often necessary for colleagues to work well together and try their best in ensuring successful accomplishment of task given.

- Effectiveness and Efficiency: This entails ability of the workers in an organization to do the right things the way they are supposed to. It also entails doing those right things in the best way.

- Trust and Openness: If an organization that imbibes trust and openness as its culture, its employees tend to have their tasks accomplished before deadline. In other words, the more the level of trust we can have in our colleagues, the more we will be able to accomplish. Cultivating trust involves everybody within the organization.

- Creative Synergy: This is a situation whereby organizations use collective creativity to achieve results that the sum of their individual effort could not achieve. When teams achieve creative synergy they have potential to be more creative and innovative.

- Effective communication: This increases productivity and job satisfaction; it decreases rate of absenteeism and employee turnover.

- Innovation and Risk taking: There cannot be any serious innovation if an organizational culture does not support risk taking. Risk taking is an essential ingredient that promotes innovation that is the practical implementation of creative ideas. Employee risk taking represent a willingness to withstand uncertainties and mistakes, as one explores new ideas and tackling new challenges without obvious solutions, in order to improve the likelihood of goal attainment.

- Viable Business Strategy: Strategy is a way by which businesses ensure a sustainable competitive advantage by investing the resources needed to develop capabilities leading to the long-term excellent performance. The dynamic business environment is being dealt with by different strategies developed by an organization.

\subsection{Concept of Performance}

Continuous performance is the target of any organization, because performance is germane to the growth and progress of an enterprise. Thus, the concept of organizational performance is one of the debatable variables in management research and it is widely used as an indicator of performance management.

Performance refers to the extent of accomplishment of the mission at place of work that builds up an employee job (Cascio, 2006). Different researchers have different thoughts about performance. Mostly researchers used the term performance to express the range of measurements of transactional efficiency and input and output efficiency (Stannack, 1996).

According to Richard Devinney, George and Johnson (2009), organizational performance encompasses three specific areas of firm outcomes: financial performance (profits, returns on assets, return on investment); product market performance (sales, market share); and shareholder return (total shareholder return, economic value added). Organizational performance does not only mean to define problem, but it also seek for solution to problem (Hefferman and Flood 2000). Daft (2000), says that organizational performance is the organization's capability to accomplish its goals effectively and efficiently using the available resources. As similar to Daft (2000), Richardo and Wade (2001) say that, achieving organizational goals and objectives is known as organizational performance. They suggest that organizations success shows high return on equity and this become possible due to establishment of good employees performance management system.

Lebans and Euske (2006) provide a set of descriptions to illustrate the concept of organizational performance: 
- Performance is a set of monetary and non-monetary indicators which offer information on the degree of achievement of objectives and results.

- Performance may be illustrated by using an essential model that describes how current actual results can work contrary or in support of the set standard in the nearest future.

- $\quad$ Performance is not fixed; therefore, it requires result and analysis of the result.

- Performance could be understood another way depending on the person involved in the evaluation of the organizational performance.

- To define the concept of performance, it is necessary to know its elements characteristic to each area of job.

- To report or describe an organization's performance level, it is necessary to be able to evaluate the result.

\subsection{Empirical Review}

A substantial number of researches have taken place in order to prove the relationship between organizational culture and business performance. In this part of the study, few researches would be presented highlighting related previous studies to show the relationship between organizational culture and performance.

The study of Raduan, Naresh, Haslinda and Ying (2008), in their samples, they took American, Japanesse, European companies operating in Malaysia. They sent the questionnaire to 240 employees in those organizations and they received only 133 responses from the respondents which means that there was a 55\% response. The respondents were only managers from the selected companies. Questionnaire was designed keeping Hofstede's (1980) cultural model in mind and questions were asked from four different dimensions - power distance, consistency, individualism and collectivism and sex of the employees. In order to measure organizational performance, five measurements were used namely financial performance, customer perspective, internal business perspective, innovation and theological appraisal. This study on corporate culture and organizational performance demonstrates that organizations that control their corporate culture in an effective way are most likely to experience higher productivity, technological advancement and better work life among employees.

Researchers of this study suggested that companies should control their culture in such a way that employees have clear idea about it, so that they can be self motivated and can devote themselves in accomplishing company's mission and objective. Expatriate managers are expected to learn the cultural values of Malaysia instead of bringing their culture within the company. This is a very much possible scenario even if the expatriates are well influenced by their own culture. However, the researchers state that, national culture does not act as a barrier for foreign companies in Malaysia, rather, foreign companies adapt with Malaysian corporate culture quite easily. They added that in an organization, managing the system and people of the company is the prime issue and it does not depend on the pure adoption of any country's culture. They opt that, management should know what business they are in and what their employees want from then and only then, they can come up with an effective corporate culture. The findings of this study are very much consistent with the findings of Cameron and Quinn (1999) and Kotter and Heskett (1992).

Denison (1984) uses data from 34 American firms on cultural performance over a period of five years, scrutinized the characteristics of organizational culture, and tracked the performance over time in these firms. Reichers and Schneider (1990) state that culture researchers have committed various studies to the definitions of culture; relatively few researchers have been contributed in culture and performance research. The only reason for doing this was the complexity in operational concept of the culture construct. According to Kotter and Heskett (1992), they investigated the relationship between long-term organizational performance and economic performance across more than 200 organizations. Moreover, the study has arranged three vital contributions, being one of the important and most conscientious researches efforts on this subject. First, relationship between culture and performance established in their research is forceful. Second, the writer gives an important combination of theoretical point of view regarding the nature \& scope of culture. Third, they sketch strong associations between culture, management practices and performance. The claim that organizational cultures are attached to performance and that it was initiated on the apparent role that culture could play in increasing competitive advantage.

According to Saffold (1998) firstly, culture can give a shape to the organizational processes, which again helps to create and modify culture. Secondly, it is likely that culture's contribution to performance is significantly less 
undemanding than many studies involve. Most of writers and successful managers suggest that strong organization culture is very essential for business because of three important functions: First, organizational culture is in line with the social control that may cause to make influence on the employee's decisions and behavior. Second, organizational culture works as social glue to bind the employees together and make them feel a strong part of the corporate experience, which is useful to attract new staff and retain the best performers. Third, organizational culture is very useful to assist the sense making process and it helps the employees to understand the organizational events and objectives, which enhance the efficiency and effectiveness of the employees.

\subsection{Methodology}

The design used for this study was descriptive. Descriptive research design is normally intended to describe and report the way things are. They are characterized by systematic collection of data from members of a given population through questionnaire and interview. Two stages sampling technique were used. At the first stage, purposive sampling technique was used to select three companies namely: Mtn, Glo, and Etisalat. At the second stage, convenience sampling was used to select 90 employees, 80 employees from Globacom and 30 employees from Etisalat making a total of 200 questionnaires were administered and this was stratified into three categories (senior, middle and junior). The responses to the questionnaires were analyzed using Statistical Package for Social Sciences (SPSS), which generated the frequency distribution, means, standard deviation, and Durbin Watson statistics among other responses.

\subsection{Data Analysis and Results}

\section{Objective 1: Identifying the existent cultures in mobile telecommunication industry}

Table 1: Distribution of Respondents in identifying the existent cultures in mobile telecommunication industry

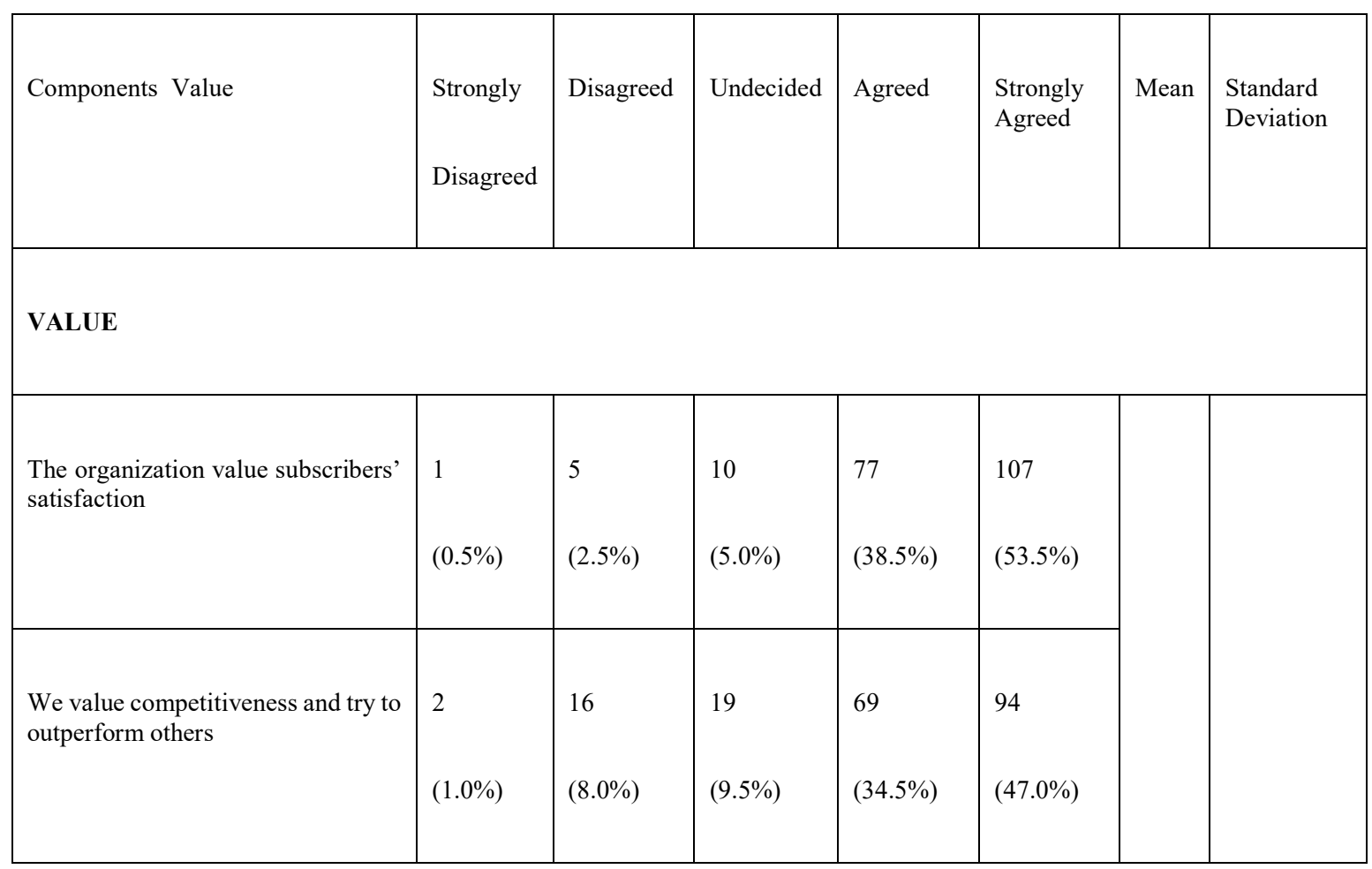




\begin{tabular}{|c|c|c|c|c|c|c|c|}
\hline $\begin{array}{l}\text { The organization defines success on } \\
\text { the basis of collaboration, strategic } \\
\text { partnership and teamwork }\end{array}$ & $\begin{array}{l}6 \\
(3.0 \%)\end{array}$ & $\begin{array}{l}8 \\
(4.0 \%)\end{array}$ & $\begin{array}{l}12 \\
(6.0 \%)\end{array}$ & $\begin{array}{l}89 \\
(44.5 \%)\end{array}$ & $\begin{array}{l}85 \\
(42.5 \%)\end{array}$ & 4.05 & 1.258 \\
\hline $\begin{array}{l}\text { The organization defines success } \\
\text { based on efficiency and } \\
\text { effectiveness }\end{array}$ & $\begin{array}{l}9 \\
(4.5 \%)\end{array}$ & $\begin{array}{l}7 \\
(3.5 \%)\end{array}$ & $\begin{array}{l}6 \\
(3.0 \%)\end{array}$ & $\begin{array}{l}108 \\
(54.0 \%)\end{array}$ & $\begin{array}{l}70 \\
(35.0 \%)\end{array}$ & & \\
\hline $\begin{array}{l}\text { There is high trust and openness } \\
\text { within the organization }\end{array}$ & $18(9.0 \%)$ & $23(11.5 \%)$ & $13(6.5 \%)$ & $95(47.5 \%)$ & $\begin{array}{l}51 \\
(25.5 \%)\end{array}$ & & \\
\hline
\end{tabular}

\section{ATTITUDE}

\begin{tabular}{|c|c|c|c|c|c|c|c|}
\hline $\begin{array}{l}\text { The organization is very results } \\
\text { oriented }\end{array}$ & $\begin{array}{l}5 \\
(2.5 \%)\end{array}$ & $\begin{array}{l}10 \\
(5.0 \%)\end{array}$ & $\begin{array}{l}13 \\
(6.5 \%)\end{array}$ & $\begin{array}{l}75 \\
(37.5 \%)\end{array}$ & $\begin{array}{l}97 \\
(48.5 \%)\end{array}$ & & \\
\hline $\begin{array}{l}\text { The organization imbibes the idea of } \\
\text { gearing up for the unknown }\end{array}$ & $\begin{array}{l}4 \\
(2.0 \%)\end{array}$ & $\begin{array}{l}32 \\
(16.0 \%)\end{array}$ & $\begin{array}{l}24 \\
(12.0 \%)\end{array}$ & $\begin{array}{l}85 \\
(42.5 \%)\end{array}$ & $\begin{array}{l}55 \\
(27.5 \%)\end{array}$ & & \\
\hline $\begin{array}{l}\text { The organization emphasizes } \\
\text { permanence and stability }\end{array}$ & $\begin{array}{l}12 \\
(6.0 \%)\end{array}$ & $\begin{array}{l}18 \\
(9.0 \%)\end{array}$ & $\begin{array}{l}17 \\
(8.5 \%)\end{array}$ & $\begin{array}{l}83 \\
(41.5 \%)\end{array}$ & $\begin{array}{l}70 \\
(35.0 \%)\end{array}$ & 3.72 & 1.154 \\
\hline
\end{tabular}




\begin{tabular}{|l|l|l|l|l|l|l|}
\hline $\begin{array}{l}\text { Management appreciates creative } \\
\text { synergy }\end{array}$ & 13 & 26 & 9 & 94 & 58 \\
\hline $\begin{array}{l}\text { Management has ability to deal with } \\
\text { inhibiting factors to growth }\end{array}$ & 9 & $(6.5 \%)$ & $(13.0 \%)$ & $(4.5 \%)$ & $(47.0 \%)$ & $(29.0 \%)$ \\
\hline
\end{tabular}

\section{BELIEFS}

\begin{tabular}{|c|c|c|c|c|c|c|c|}
\hline $\begin{array}{l}\text { Management does an excellent job } \\
\text { of communicating with employees } \\
\text { on a host of issues }\end{array}$ & $\begin{array}{l}10 \\
(5.0 \%)\end{array}$ & $\begin{array}{l}29 \\
(14.5 \%)\end{array}$ & $\begin{array}{l}11 \\
(5.5 \%)\end{array}$ & $\begin{array}{l}88 \\
(44.0 \%)\end{array}$ & $\begin{array}{l}62 \\
(31.0 \%)\end{array}$ & & \\
\hline $\begin{array}{l}\text { Management encourages innovation } \\
\text { and risk taking }\end{array}$ & $\begin{array}{l}15 \\
(7.5 \%)\end{array}$ & $\begin{array}{l}33 \\
(16.5 \%)\end{array}$ & $\begin{array}{l}20 \\
(10.0 \%)\end{array}$ & $\begin{array}{l}86 \\
(43.0 \%)\end{array}$ & $\begin{array}{l}46 \\
(23.0 \%)\end{array}$ & & \\
\hline $\begin{array}{l}\text { Employees tenure is generally } \\
\text { strong }\end{array}$ & $\begin{array}{l}16 \\
(8.0 \%)\end{array}$ & $\begin{array}{l}34 \\
(17.0 \%)\end{array}$ & $\begin{array}{l}27 \\
(13.5 \%)\end{array}$ & $\begin{array}{l}80 \\
(40.0 \%)\end{array}$ & $\begin{array}{l}43 \\
(21.5 \%)\end{array}$ & & \\
\hline $\begin{array}{l}\text { Management is constantly looking } \\
\text { for ways to improve products and } \\
\text { services }\end{array}$ & $\begin{array}{l}3 \\
(1.5 \%)\end{array}$ & $\begin{array}{l}12 \\
(6.0 \%)\end{array}$ & $\begin{array}{l}15 \\
(7.5 \%)\end{array}$ & $\begin{array}{l}85 \\
(42.5 \%)\end{array}$ & $\begin{array}{l}85 \\
(42.5 \%)\end{array}$ & 4.19 & 1.248 \\
\hline $\begin{array}{l}\text { Management shares business } \\
\text { strategies with employees }\end{array}$ & $\begin{array}{l}12 \\
(6.0 \%)\end{array}$ & $\begin{array}{l}26 \\
(13.0 \%)\end{array}$ & $\begin{array}{l}15 \\
(7.5 \%)\end{array}$ & $\begin{array}{l}85 \\
(42.5 \%)\end{array}$ & $\begin{array}{l}62 \\
(31.0 \%)\end{array}$ & & \\
\hline
\end{tabular}




\begin{tabular}{|l|l|l|l|l|l|l|l|}
\hline & & & & & & & \\
\hline
\end{tabular}

BEHAVIOUR

\begin{tabular}{|c|c|c|c|c|c|c|c|}
\hline $\begin{array}{l}\text { Management puts a great deal of } \\
\text { effort into hiring new employees } \\
\text { who will fit into the organization }\end{array}$ & $\begin{array}{l}5 \\
(2.5 \%)\end{array}$ & $\begin{array}{l}23 \\
(11.5 \%)\end{array}$ & $\begin{array}{l}13 \\
(6.5 \%)\end{array}$ & $\begin{array}{l}103 \\
(51.5 \%)\end{array}$ & $\begin{array}{l}56 \\
(28.0 \%)\end{array}$ & & \\
\hline $\begin{array}{l}\text { Management encourages and } \\
\text { rewards specific behaviour }\end{array}$ & $\begin{array}{l}10 \\
(5.0 \%)\end{array}$ & $\begin{array}{l}30 \\
(15 \%)\end{array}$ & $\begin{array}{l}18 \\
(9.0 \%)\end{array}$ & $\begin{array}{l}88 \\
(44.0 \%)\end{array}$ & $\begin{array}{l}54 \\
(27.0 \%)\end{array}$ & & \\
\hline $\begin{array}{l}\text { Management encourages all } \\
\text { employees to challenge how things } \\
\text { are done }\end{array}$ & $\begin{array}{l}14 \\
(7.0 \%)\end{array}$ & $\begin{array}{l}24 \\
(12.0 \%)\end{array}$ & $\begin{array}{l}15 \\
(7.5 \%)\end{array}$ & $\begin{array}{l}93 \\
(46.5 \%)\end{array}$ & $\begin{array}{l}54 \\
(27.0 \%)\end{array}$ & & \\
\hline $\begin{array}{l}\text { Management is quick to deal with } \\
\text { problem relating to performance }\end{array}$ & $\begin{array}{l}15 \\
(7.5 \%)\end{array}$ & $\begin{array}{l}21 \\
(10.5 \%)\end{array}$ & $\begin{array}{l}9 \\
(4.5 \%)\end{array}$ & $\begin{array}{l}91 \\
(45.5 \%)\end{array}$ & $\begin{array}{l}64 \\
(32.0 \%)\end{array}$ & 3.72 & 1.188 \\
\hline $\begin{array}{l}\text { Management is disciplined with } \\
\text { employees performance feedback } \\
\text { and appraisals }\end{array}$ & $\begin{array}{l}13 \\
(6.5 \%)\end{array}$ & $\begin{array}{l}21 \\
(10.5 \%)\end{array}$ & $\begin{array}{l}11 \\
(5.5 \%)\end{array}$ & $\begin{array}{l}97 \\
(48.5 \%)\end{array}$ & $\begin{array}{l}58 \\
(29.0 \%)\end{array}$ & & \\
\hline
\end{tabular}

\section{NORMS}




\begin{tabular}{|c|c|c|c|c|c|c|c|}
\hline $\begin{array}{l}\text { We have particular slogans in our } \\
\text { organization }\end{array}$ & $\begin{array}{l}5 \\
(2.5 \%)\end{array}$ & $\begin{array}{l}14 \\
(7.0 \%)\end{array}$ & $\begin{array}{l}18 \\
(9.0 \%)\end{array}$ & $\begin{array}{l}75 \\
(37.5 \%)\end{array}$ & $\begin{array}{l}88 \\
(44.0 \%)\end{array}$ & & \\
\hline $\begin{array}{l}\text { We appreciates specific colours in } \\
\text { or organization }\end{array}$ & $\begin{array}{l}7 \\
(3.5 \%)\end{array}$ & $\begin{array}{l}21 \\
(10.5 \%)\end{array}$ & $\begin{array}{l}15 \\
(7.5 \%)\end{array}$ & $\begin{array}{l}70 \\
(35.0 \%)\end{array}$ & $\begin{array}{l}87 \\
(43.5 \%)\end{array}$ & & \\
\hline $\begin{array}{l}\text { Employees engage in a host of } \\
\text { socialization activities in and out of } \\
\text { the workplace. }\end{array}$ & $\begin{array}{l}9 \\
(4.5 \%)\end{array}$ & $\begin{array}{l}22 \\
(11.0 \%)\end{array}$ & $\begin{array}{l}19 \\
(9.5 \%)\end{array}$ & $\begin{array}{l}94 \\
(47.0 \%)\end{array}$ & $\begin{array}{l}56 \\
(28.0 \%)\end{array}$ & 4.04 & 1.110 \\
\hline $\begin{array}{l}\text { The organization performs their } \\
\text { social responsibilities }\end{array}$ & $\begin{array}{l}15 \\
(7.5 \%)\end{array}$ & $\begin{array}{l}20 \\
(10.0 \%)\end{array}$ & $\begin{array}{l}14 \\
(7.0 \%)\end{array}$ & $\begin{array}{l}77 \\
(38.5 \%)\end{array}$ & $\begin{array}{l}74 \\
(37.0 \%)\end{array}$ & & \\
\hline $\begin{array}{l}\text { There is cordial relationship among } \\
\text { the employees }\end{array}$ & $\begin{array}{l}11 \\
(5.5 \%)\end{array}$ & $\begin{array}{l}15 \\
(7.5 \%)\end{array}$ & $\begin{array}{l}13 \\
(6.5 \%)\end{array}$ & $\begin{array}{l}88 \\
(44.0 \%)\end{array}$ & $\begin{array}{l}73 \\
(36.5 \%)\end{array}$ & & \\
\hline
\end{tabular}

\section{Source: Field Survey, 2016}

\section{Discussion of findings}

\section{Value and its components}

As summarized in Table 1, on the existence of value culture in telecommunication industry, 84 respondents representing 52.5\%, strongly agreed, $64(40.0 \%)$ respondents agreed, while $7(4.4 \%)$ were neutral, $4(2.8 \%)$ disagreed and just $1(0.6 \%)$ strongly disagreed. The respondents that selected strongly agreed and agreed were higher in number compared to other options. This means that value and its components are significant part of organization culture of telecommunication industry. This was supported by mean of 4.41 on the scale of 5 . 


\section{Attitudes and its components}

In the case of Attitudes components in Table 1, 72 respondents with 49.4\% strongly agreed, 62 (38.8\%) agreed while $10(6.3 \%)$ were neutral $7(4.4 \%)$ and $2(1.3 \%)$ were disagreed and strongly disagreed respectively. This is being supported by mean of 4.31 on the scale of 5 . The organization that has attitude and its components as part of their culture will likely soar higher.

\section{Beliefs and its components}

Part of summary in Table 1, also shows the view of respondent in respect of belief in an organizational culture, 47 respondents strongly agreed with percentage of $29.4,71$ agreed with $44.4 \%$, while $9(9.6 \%)$ respondents were neutral and $23(14.4 \%)$ and $9(5.6 \%)$ respondents disagreed and strongly disagreed respectively. The significant of the belief and its components of communication, innovation and risk taking, improvement of product and services and viable business strategies were all confirmed by the mean of 4.19 on the scale of 5 .

\section{Behaviour and its components}

As summarized in Table 1, the number of respondents that strongly agreed were $44(27.5 \%)$ and those that agreed were $79(49.4 \%)$, while $11(6.9 \%)$ did not decide; $21(13.1 \%)$ and $5(3.1 \%)$ disagreed and strongly disagreed respectively. The degree of responses revealed that the behaviour and its component pave way for improvement in performance of an organization.

\section{Norms and it components}

In the case of norms of telecommunication industry, 69(43.1\%) respondents strongly agreed, 59(36.9\%) respondents agreed while $16(10.0 \%)$ were neutral, $12(7.5 \%)$ and $3(1.9 \%)$ disagreed and strongly disagreed respectively. This means that the good numbers of respondents see norms and its component as significant to their organization and its mean value is 4.13 with standard deviation of 0.998 .

\section{Objective 2: Factors influencing Culture of mobile telecommunication companies in Nigeria}

Table 2: Distribution of Respondents' perception on the Factors influencing Organization Culture

\begin{tabular}{|l|l|l|l|l|l|l|l|}
\hline Components & Strongly & Disagreed & Undecided & Agreed & $\begin{array}{l}\text { Strongly } \\
\text { Agreed }\end{array}$ & Mean & STD \\
\hline Disagreed & & & & & & \\
\hline National cultures & & & & & \\
\hline
\end{tabular}




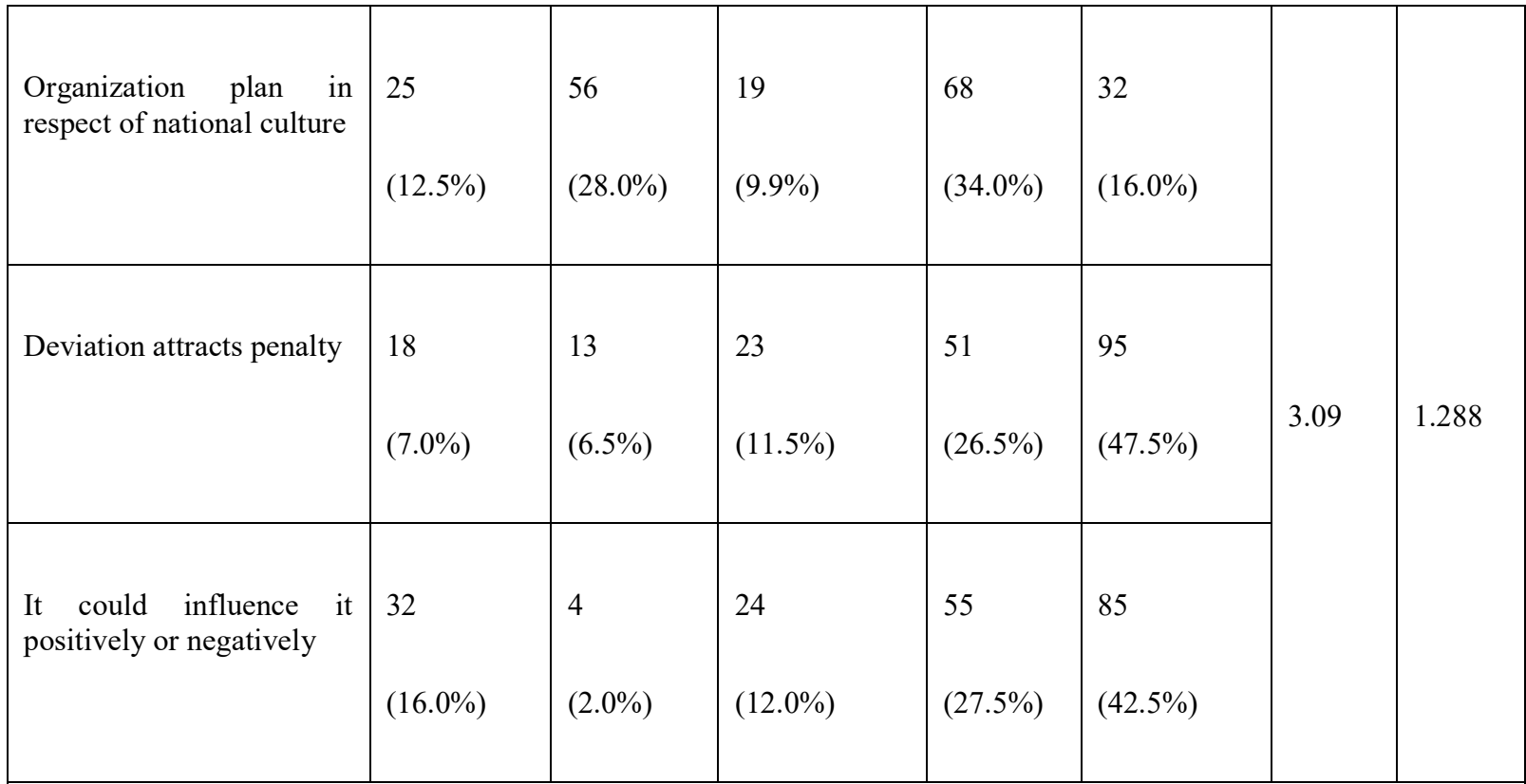

\section{Government Economic policies}

\begin{tabular}{|c|c|c|c|c|c|c|c|}
\hline $\begin{array}{l}\text { Government policies } \\
\text { influence internal policy } \\
\text { of the companies }\end{array}$ & & & & & & & \\
\hline & $\begin{array}{l}13 \\
(6.5 \%)\end{array}$ & $\begin{array}{l}38 \\
(19.0 \%)\end{array}$ & $\begin{array}{l}20 \\
(10.0 \%)\end{array}$ & $\begin{array}{l}91 \\
(45.5)\end{array}$ & $\begin{array}{l}38 \\
(19.0 \%)\end{array}$ & & \\
\hline $\begin{array}{l}\text { It has direct effect on the } \\
\text { performance of the } \\
\text { company }\end{array}$ & $\begin{array}{l}10 \\
(5.0 \%)\end{array}$ & $\begin{array}{l}1 \\
(0.5 \%)\end{array}$ & 5 & $\begin{array}{l}107 \\
(53.5 \%)\end{array}$ & $\begin{array}{l}77 \\
(38.5 \%)\end{array}$ & 3.49 & 1.208 \\
\hline $\begin{array}{l}\text { There is total compliance } \\
\text { with the policies }\end{array}$ & $\begin{array}{l}8 \\
(4.0 \%)\end{array}$ & $\begin{array}{l}6 \\
(3.0 \%)\end{array}$ & $\begin{array}{l}12 \\
(6.0 \%)\end{array}$ & $\begin{array}{l}85 \\
(42.5 \%)\end{array}$ & $\begin{array}{l}89 \\
(44.5 \%)\end{array}$ & & \\
\hline
\end{tabular}

\section{Industry norms}




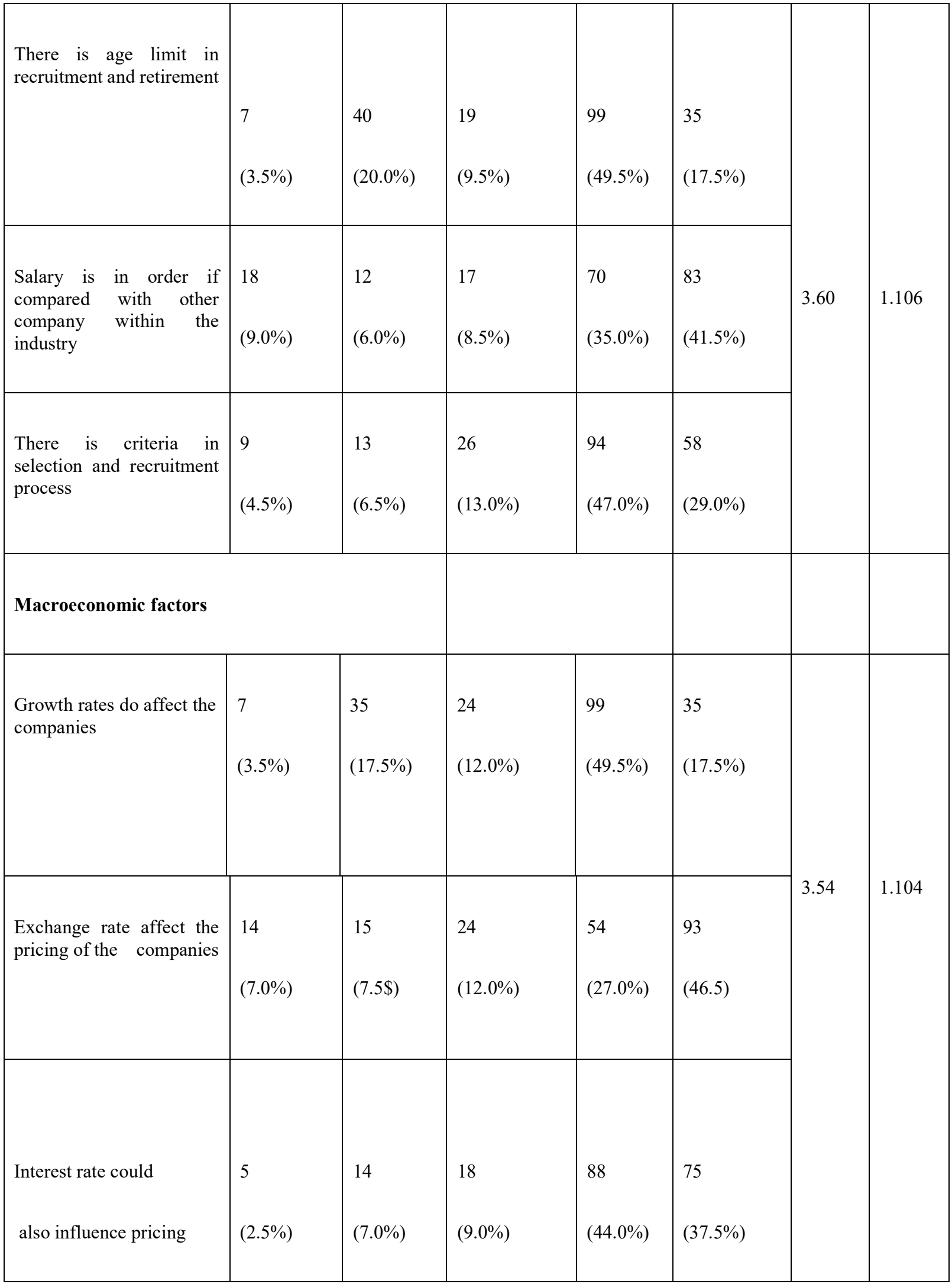




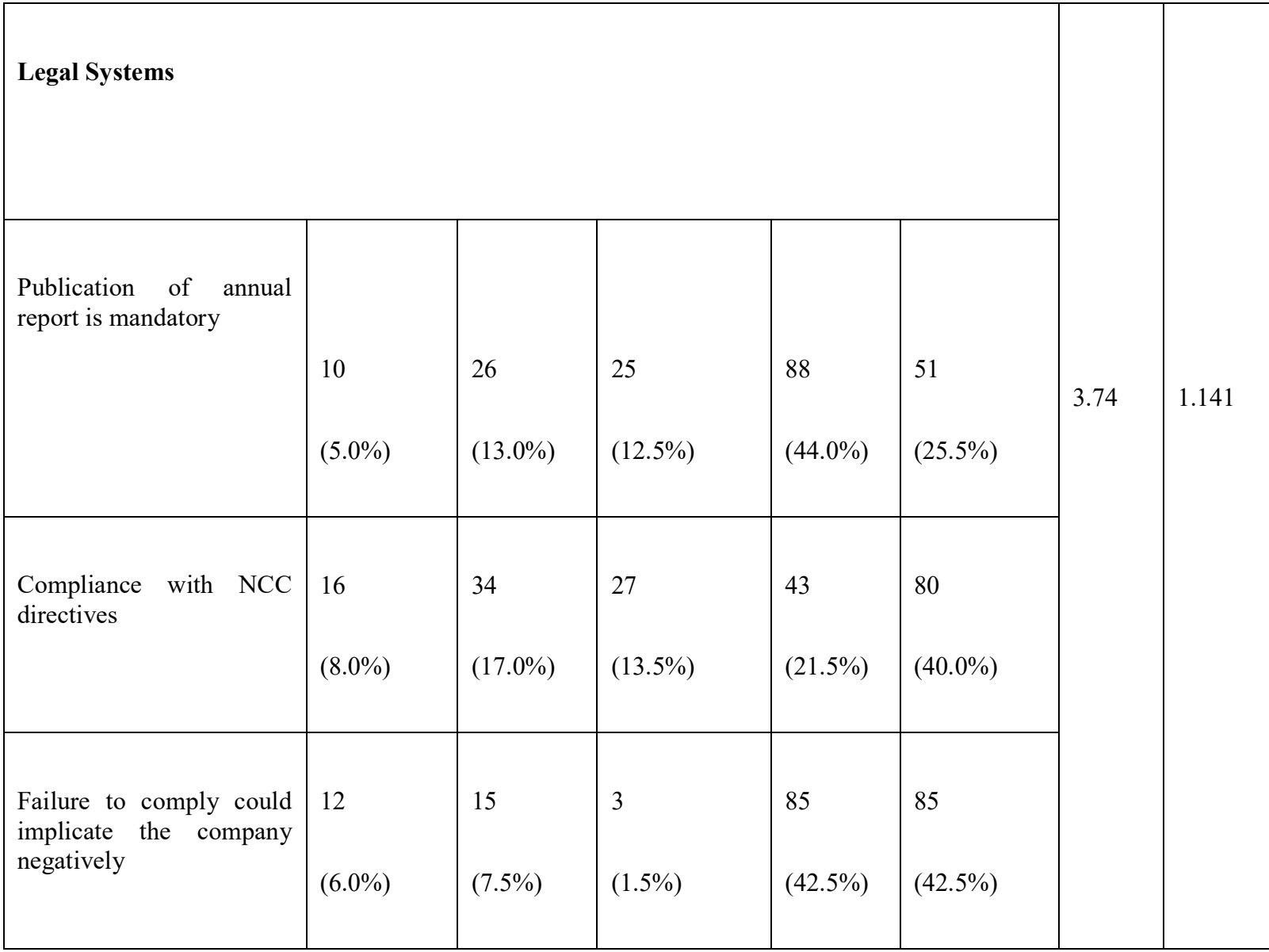

Source: Field Survey, 2016

\section{Discussion of findings}

\section{National Cultures and its Components}

The influence of national culture and its components on the telecom companies' 68 respondents representing $34.0 \%$ agreed that it had influence, 32 respondents representing $16.0 \%$ strongly agreed that it had influence and 19 respondents representing 9.9\% were neutral and 56 and 25 respondents representing $28.0 \%$ and $12.5 \%$ respectively disagreed with its influence. The high level of agreement supported by a mean value of 3.09 on a scale of 5.0 indicating that national cultures influenced organizational culture

\section{Components of Government Economic Policies}

With regards to the policy of a government in Nigeria on how it influenced the telecom companies, 91 respondents representing $45.5 \%$ agreed that it had influence, 38 respondents representing $19.0 \%$ strongly agreed that it had influence, 20 respondents representing $10.0 \%$ were undecided as to its influence while 38 and 13 respondents representing $19.0 \%$ and $6.5 \%$ respectively disagreed with its influence on organizational culture. This high level of agreement by the respondents was confirmed by a mean value of 3.49 indicating that economic policies influence organizational cultures in the telecom industry in Nigeria (see Table 2). 


\section{Industry Norms and its Components}

In case of industrial norms of the telecom companies, 35 respondents representing $17.5 \%$ strongly agreed to its influence 99 respondents representing 49.5\% strongly agreed that it had influence, while 19 respondents representing $9.5 \%$ were undecided, 40 and 7 respondents representing $20.0 \%$ and $3.5 \%$ respectively disagreed with its influence. These high levels of agreement were corroborated by a mean value of 3.60 on the scale of 5.0 indicating that norms in the industry influence organizational culture in the telecom companies.

\section{Macroeconomic Factors}

Regarding the macroeconomic factors such as exchange rate to influence organizational culture of a telecom company, 35 respondents representing $17.5 \%$ strongly agreed; 99 respondents representing $49.5 \%$ agreed with it, while 24 respondents representing $12.0 \%$ were neutral and 35 and 7 respondents representing $17.5 \%$ and $3.5 \%$ respectively disagreed and strongly disagreed. The position of the majority was confirmed by a high mean value of 3.54 on a scale of 5.0 point of rating which indicates that macroeconomic factors influence organizational culture of telecom companies

\section{Legal System}

In case of legal systems of a company, 51 respondents representing $25.5 \%$ strongly agreed with it; 88 respondents representing $44.0 \%$ agreed while 25 respondents representing $12.5 \%$ were neutral and 26 and 10 respondents representing $13.0 \%$ and $5.0 \%$ respectively disagreed and strongly disagreed with its influence on organizational culture. The high level of agreement was supported by a mean value of 3.74 on the scale of 5 showing that the cultures of telecommunication companies were affected by the legal systems of a country.

\subsection{Test of hypothesis one}

Null hypothesis one $\left(\mathrm{H}_{0}\right)$ : There are no significant factors influencing organizational culture in mobile telecommunication companies in Nigeria.

(A) Model for assessing the factors influencing organizational culture in telecommunication companies in Nigeria $y=\beta 0+\beta 1 X 1+\beta 2 X 2+\beta 3 X 3+\beta 4 X 4+\beta 5 X 5+e i--------------(1)$

Where, $y=$ dependent variable, that is Organizational culture (ORGCUL). This is measured by using changes in responses of agreed and disagreed respondents on identified culture in the telecommunication companies as proxy assuming the influence of undecided respondents to be insignificant.

$\mathrm{X} 1=$ Independent variable, that is organizational culture due to national culture (NATCUL)

$\mathrm{X} 2=$ Organizational culture due to Government economic policies (GEP)

$\mathrm{X} 3=$ Organizational culture due to industry norms (INDNOR)

$\mathrm{X} 4=$ Organizational culture due to macro economic factors (MACROECO)

X5= Organizational culture due to legal system (LEGSYS) 
Also, $\beta 0=$ Intercept, that is, the organizational culture that is not as a results any factors while $\beta 1-\beta 5$ are the parameters to be estimated and ei= error term.

A priori expectation for the model is that, $\beta 1$ to $\beta 5>0$.

Table 3: F-calculated for testing the overall influence of factors influencing organizational culture in Telecommunication in Nigeria

\begin{tabular}{|c|c|c|c|c|c|}
\hline SV & SS & $\begin{array}{l}\mathrm{D} \\
\mathrm{F}\end{array}$ & MS & $\begin{array}{l}\text { F- } \\
\text { RATI } \\
\text { O }\end{array}$ & SIG. \\
\hline $\begin{array}{l}\text { R } \\
\text { e } \\
\text { g } \\
r \\
\text { e } \\
\mathrm{s} \\
\mathrm{s} \\
\mathrm{i} \\
\mathrm{o} \\
\mathrm{n}\end{array}$ & $\begin{array}{l}32367.6 \\
72\end{array}$ & 5 & $\begin{array}{l}6473.5 \\
34\end{array}$ & $\begin{array}{l}273.6 \\
30\end{array}$ & $\begin{array}{l}0.00 \\
00\end{array}$ \\
\hline Residual & 567.803 & 24 & 23.658 & & \\
\hline Total & $\begin{array}{l}32935.4 \\
75\end{array}$ & 29 & & & \\
\hline
\end{tabular}

Source: Author's computation, 2016 
Table 4: T-calculated for testing the overall influence of factors influencing organizational culture in Telecommunication in Nigeria

\begin{tabular}{|c|c|c|c|c|c|}
\hline Predictors & $\begin{array}{l}\text { Unstan } \\
\text { coeffici }\end{array}$ & rdized & $\begin{array}{l}\text { Standardized } \\
\text { coefficient }\end{array}$ & T-calculated & P-Value \\
\hline & $\mathrm{B}$ & Std.Error & Beta & & \\
\hline $\operatorname{NATCUL}\left(\mathrm{X}_{1}\right)$ & 34.672 & 1.034 & 0.984 & 33.532 & 0.000 \\
\hline $\operatorname{GEP}\left(\mathrm{X}_{2}\right)$ & 0.892 & 0.045 & 0.056 & 19.822 & 0.000 \\
\hline $\operatorname{INDNOR}\left(\mathrm{X}_{3}\right)$ & 1.290 & 0.061 & 0.761 & 21.148 & 0.000 \\
\hline $\operatorname{MACROECO}\left(\mathrm{X}_{4}\right)$ & 0.589 & 0.094 & 0.023 & 6.262 & 0.013 \\
\hline LEGSYS $\left(\mathrm{X}_{5}\right)$ & 23.450 & 3.124 & 0.042 & 7.506 & 0.003 \\
\hline Constant & 0.786 & 3.004 & - & 0.262 & 0.765 \\
\hline
\end{tabular}

Source: Author's computation, 2016 
Table 5: Coefficient of determination $\left(R^{2}\right)$ Obtained for verifying the overall contribution of factors influencing organizational on culture of the selected telecommunication companies

\begin{tabular}{|l|l|l|l|l|}
\hline $\mathrm{R}$ & $\mathrm{R}^{2}$ & Adjusted $\mathrm{R}^{2}$ & $\begin{array}{l}\text { Standard error of } \\
\text { estimate }\end{array}$ & $\begin{array}{l}\text { Durbin-Watson } \\
\text { Statistics }\end{array}$ \\
\hline 0.998 & 0.996 & 0.994 & 0.321 & 2.023134 \\
\hline
\end{tabular}

Source: Author's Computation, 2016

\section{Interpretation}

Tables 3 to 5 above present the results of the test statistics compute for the null hypothesis one. In table 3, the pvalue of the F-statistics computes for testing the overall significant of the null hypothesis one of 0.0000 , is less than the critical value of $5 \%$. This implies that the null hypothesis which states that there are no significant factors influencing organizational culture in telecommunication companies in Nigeria is rejected. In table 4.6, the p-value for testing the significant of national culture as one of the factors influencing organizational culture of 0.000 is less than the critical value of $5 \%$. This implies that the null hypothesis which states that national culture has no influence on organizational culture is rejected. In fact, the p-values of government policies, industry norms, macroeconomic factors and legal system of $0.0000,0.0000,0.013$ and 0.003 respectively are less than the critical value of $5 \%$. This indicates that Government policies, industry norms, macro-economic factors and legal system influence organizational culture in mobile telecommunication companies in Nigeria. In fact, the regression coefficient obtains for national culture of 34.672 indicates an existence of a positive relationship between national culture and culture of the mobile telecommunication companies in Nigeria. This further reveals that no telecommunication companies in the country can go against the culture of the nation. For instance, if national culture requires compulsory registration of all active 'SIM' subscribed in Nigeria no telecommunication company can go against it. Therefore, national culture and culture of the telecommunication company in the country are directly related. It can be asserted that, there is a positive relationship between government policy, industry norms, macro economic factors, legal system and organizational culture. This assertion is based on the fact that the regression coefficients obtain for Government policies, industry norms, macro economics factors and legal system of $0.892,1.290,0.589$ and 23.450 are all positive which is in line with the priori expectation for the model.

Also, in table 4 , the coefficient of determination $\left(\mathrm{R}^{2}\right)$ obtains of 0.996 indicates the fact that $99.60 \%$ of organizational culture in Nigerian mobile telecommunication is due to national culture, government policy, industry norms, macro-economic factors and legal system. Therefore, national cultures, government policy, industry norms, macro-economic factors and legal system are good predictors' variables for organizational culture in Nigerian telecommunication companies. Furthermore, the Durbin-Watson coefficient obtains of 2.023134 reveals the existence of a minimal auto-correlation among the variables of the study; hence, the predictors' variables of the study have the ability to also influence the culture of the telecommunication industries in Nigeria in the long run. 


\subsection{Conclusion and Recommendations}

\section{Conclusion}

This study concluded that organization culture in mobile telecommunication companies include: Customeroriented, Competitiveness, Teamwork, Creative Synergy, Stability, Effective Communication, Innovation and Risk taking and Viable Business Strategy.

The study also showed that the mobile telecommunication companies' cultures' are being influenced by Government economy policy, Industry norms, Macroeconomic factors and Legal system of a country. Factors that influence culture they should be given attention so as to prevent its negative effect on their performance.

\section{Recommendations}

Given the roles that the existent cultures played in performance of mobile telecommunication, companies' managers should endeavour to understand them by devising means of strengthening and applying them on their day to day activities.

The factors that influence the organizational culture should be reduced to the barest minimum level in order to thrive and perform as expected. Since organizational culture project the image of the organization there is need for the managers to reiterate them to their employees and punish any deviants appropriately.

Finally, management should endeavour to examine the effects that the organizational culture had on business performance. They should ensure that the employees' morale were high; they should also put in place a clear set of values that underpin business performance; seeks feedback from clients and customers with a view to improving services. Furthermore, they should ensure that there is a high rate of sales turnover because of those cultures.

\subsection{Contribution to knowledge}

The result of this study will contribute to knowledge about the factors that influences organizational culture which include national culture, government policies, industry norms, macro-economic factors and legal system. Having realized this basic influential factors, caution must be taken by the mobile telecommunication companies in Nigeria about choice and application of culture, so that their internal system will not thwart sustenance of national development.

\section{REFERENCES}

Buchanan, D. and A. Huczynski, (2004). “Organizational Behaviour: An Introductory Text”. 5 ${ }^{\text {th }}$ ed. Essex: Prentice Hall Financial Times.

Cameron, K. S. \& R. E. Quinn, (1999). "Diagnosing and Changing Organizational Culture: Based on the Competing Values Framework”. Prentice Hall, ISBN 978-0-201-33871-3, reprinted John Wiley \& Sons, 2011.

Cascio, W. F. (2006). Managing Human Resources: Productivity, Quality of Life, Profits McGraw-Hill Irwin. 
Daft, R. H. (2005). Organization Theory and Design. $7^{\text {th }}$ Ed. South-Western College Publishing, Thompson Learning. U.S.A.

Denison, D. R. (1984). "Bringing corporate culture to the bottom line”. Organizational Dynamics 13, 5-22.

Heffernan, N. M., P. C. Flood, (2000). An Exploration of the Relationship between Managerial Competencies Organizational, Characteristics and Performance in an Irish organization. Journal of European Industrial Training. University Press, 128-136.

Hofstede, G. (1980).” Culture's Consequences: International Differences in Work-Related Values”. Beverly Hills, CA: Sage.

Kotter, J. P., and J. L. Heskett, (1992). “Corporate Culture and Performance”. New York: The Free Press.

Lebans, M., Euske, K. (2006), “A conceptual and operational delineation of performance”, Business Performance Measurement, Cambridge University Press.

Raduan, C. R., K., Naresh, A., Haslinda, \& Y. L., Goh, (2008), 'Organizational culture as a root of performance improvement: Research and recommendations”, Contemporary Management Research, 4(1), 43-56

Reichers, A. and B. Schneider, (1990). "Climate and culture: an evolution of constructs, in Schneider, B. (Ed.), Organizational Climate and Culture”. Jossey-Bass, San Francisco, CA, 5-39.

Richard, P.J., T.M., Devinney, S.Y., George and G. Johnson, (2009). Measuring Organisational Performance: Towards Methodological Best Practices. Journal of Management, 35(3), 718-804.

Ricardo, R. and D. Wade, (2001). "Corporate Performance management: How to Build a better Organization through Measurement Driven Strategies Alignment”. Butterworth Heinemann.

Saffold, G.S. (1998). "Culture Traits, Strength, and Organizational Performance: Moving beyond Strong Culture". The Academy of Management Review, 13, 546-558.

Stannack, P. (1996). "Perspective on Employees Performance”. Management Research News, 119 (4/5), 38-40.

\section{Biography of the Author}

Ajayi Christiana Olalounpe obtained a Bachelor degree in Business Administration and Masters degree in Business Administration at Obafemi Awolowo University, Ile-Ife, Osun state Nigeria. She teaches Business Management and Human Resource Management at the Department of Business Administration, Joseph Ayo Babalola University (JABU). She is an Associate member of Chattered Institute of Personnel Management (ACIPM). Her research focuses on Human Resource Management. She is currently studying Ph.D in Business Administration. 